\title{
Hidrotoraks Masif Dekstra dengan Penyulit ARDS Akibat Komplikasi Pemasangan Kateter Vena Sentral Jugular Interna
}

\author{
Kinanti Narulita Dewi, ${ }^{1,2}$ Wiwi Jaya, ${ }^{3}$ Arie Zainul Fatoni ${ }^{3}$ \\ ${ }^{1}$ Residen Anestesiologi \& Terapi Intensif, Fakultas Kedokteran, Universitas Brawijaya, RSUD \\ Dr. Saiful Anwar, Malang, ${ }^{2}$ Departemen Farmakologi, Fakultas Kedokteran, Universitas Islam \\ Sultan Agung, Semarang, ${ }^{3}$ Spesialis Anestesi \& Konsultan Intensive Care, Fakultas Kedokteran, \\ Universitas Brawijaya, RSUD Dr. Saiful Anwar, Malang
}

\begin{abstract}
Abstrak
Hidrotoraks merupakan komplikasi yang jarang terjadi akibat pemasangan kateter vena sentral dengan angka insidensi $0,4-1,0 \%$. Insidensi komplikasi mekanik lebih rendah pada insersi vena jugularis dibanding dengan vena subklavia. Pada kasus ini, kami melaporkan pasien laki-laki berusia 63 tahun dengan berat badan 70 kg. Pasien dengan ASA 4E sepsis dan curiga keganasan. Pasien ini didiagnosis akut abdomen karena total bowel obstruction dan rencana dilakukan tindakan laparotomi dengan anestesi umum. Pasien ini telah dipasang kateter vena sentral saat di IGD. Pasien dilakukan tindakan anestesi umum selama 3 jam dan mendapatkan cairan intraoperatif $1.500 \mathrm{cc}$ melalui kateter vena sentral. Pascaoperasi, pasien tidak dapat dilakukan ekstubasi karena napas tidak adekuat dan hemodinamik tidak stabil sehingga pasien dirawat di ruang ICU. Saat pasien tiba di ruang ICU, pada pemeriksaan fisis ditemukan suara napas paru kanan menurun dan perkusi redup pada paru kanan. Hasil analisis gas darah menunjukkan hipoksemia berat dan asidosis. Pemeriksaan foto rontgen dada ditemukan gambaran efusi pleura masif. Kami melakukan evakuasi kurang lebih 2,2 liter cairan berwarna kemerahan dari kavum pleura dan memasang selang chest tube pada paru kanan. Pasien mengalami acute respiratory distress syndrome (ARDS). Tata laksana pasien dengan sepsis dan ARDS berfokus pada prinsip lung protective strategy dan sepsis bundle sesuai dengan surviving sepsis campaign (SSC) 2018.
\end{abstract}

Kata kunci: ARDS, hidrotoraks, kateter vena sentral, komplikasi, sepsis

\section{Right Massive Hydrothorax with ARDS due to Complication of Internal Jugular Central Venous Catheter Insertion}

\begin{abstract}
Hydrothorax is a rare complication seen in approximately $0.4-1.0 \%$ of all catheter placements. The major mechanical complication incidence of internal jugular vein insertion is lower than the one in the subclavia vein. This study presented a case of a 63-year-old, $70 \mathrm{~kg}$ man with ASA 4E sepsis and suspected malignancy. Patient was diagnosed with acute abdomen pain due to total bowel obstruction and underwent exploratory laparotomy with general anesthesia. A right jugular central venous catheter (CVC) was inserted in the ER. Patient was under general anesthesia for 3 hours and 1,500 cc intra operative fluid was administered through the CVC. After surgery, the patient experienced extubation failure and was admitted to ICU because of inadequate spontaneous breathing and hemodynamic instability. Patient experienced reduced breath sound and the resonance to percussion was dull in the right hemithorax. The BGA presented severe hypoxemia and acidosis while the chest $\mathrm{x}$-ray showed right sided massive pleural effusion. Almost 2.2 liter of clear reddish fluid was drained from pleural cavity and a chest tube was inserted. Patient was then diagnosed as having acute respiratory distress syndrome (ARDS). Treatment for sepsis and ARDS was then given by focusing on the principle of lung protective strategy and sepsis bundle according to surviving sepsis campaign (SSC) 2018.
\end{abstract}

Key words: ARDS, complication, CVC, hydrothorax, sepsis

Korespondensi: Kinanti Narulita Dewi, MD, Departemen Anestesiologi \& Terapi Intensif, Fakultas Kedokteran, Universitas Brawijaya/RSUD Dr. Saiful Anwar, Malang, Indonesia, Jl. Jaksa Agung Suprapto No. 2 Malang, Indonesia, Tlpn 0341-362101, Email: kinantinarulita@gmail.com 


\section{Pendahuluan}

Pemasangan akses vena sentral merupakan prosedur yang lazim dikerjakan pada pasien kritis dan merupakan bagian dari perawatan pasien di ruang Intensive Care Unit (ICU). ${ }^{1,2}$ Indikasi pemasangan kateter vena sentral (central venous catheter; $\mathrm{CVC}$ ) antara lain untuk pemantauan status hemodinamik pasien, kateterisasi arteri pulmonar, pemasangan transvenous pacemaker darurat, hemodialisis, hipovolemik berat karena akses perifer sulit dipasang, total parenteral nutrition, dan pemberian obat-obat yang bersifat iritatif apabila diberikan melalui jalur perifer. ${ }^{1}$

Pemasangan kateter vena sentral berkaitan dengan beberapa komplikasi. Data di Amerika Serikat menyatakan bahwa komplikasi akibat pemasangan kateter vena sentral terjadi hampir 15\%.3 Prosedur ini merupakan prosedur invasif, ${ }^{2}$ komplikasi paling banyak terjadi karena mekanik (5-19\%), infeksi (526\%), dan trombosis (2-26\%). ${ }^{1}$ Komplikasi yang bersifat segera antara lain biasanya terjadi akibat mekanik, antara lain pneumotoraks, hemotoraks, dan puncture arteri. ${ }^{4}$ Beberapa dapat menyebabkan komplikasi yang serius hingga mengancam nyawa seperti perforasi vena, sepsis, dan emboli. ${ }^{5}$ Akibat komplikasi tersebut dapat meningkatkan lama dan biaya perawatan di ICU serta meningkatkan morbiditas dan mortalitas. ${ }^{1}$

Komplikasi hidrotoraks disebabkan oleh pemasangan CVC dan sangat jarang terjadi, ${ }^{6}$ dengan angka insidensi sebesar 0,4-1,0\%. ${ }^{7}$ Insidensi komplikasi tersebut lebih rendah pada insersi vena jugularis dibanding dengan insersi pada vena subklavia dan lebih rendah pada pria dibanding dengan wanita. ${ }^{8} \mathrm{Hal}$ ini dapat terjadi akibat darah, cairan infus, atau cairan limfatik yang bocor sehingga masuk ke dalam rongga pleura yang bertekanan rendah. Pasien dapat mengalami sianosis, dispneu, takikardia, hipotensi, dan nyeri dada. ${ }^{5}$ Injuri langsung pada paru dapat menyebabkan acute respiratory distress syndrome (ARDS). Pada laporan kasus ini menyatakan kasus komplikasi yang jarang akibat pemasangan kateter vena sentral via vena jugular interna dekstra berupa hidrotoraks masif dekstra dengan penyulit ARDS.

\section{Laporan Kasus}

Seorang laki-laki berusia 63 tahun, berat badan $70 \mathrm{~kg}$ dibawa ke Instalasi Gawat Darurat (IGD) oleh keluarganya dengan keluhan tidak dapat $B A B$ dan flatus sejak seminggu yang lalu disertai perut agak membesar. Pasien ini didiagnosis akut abdomen karena total bowel obstruction yang dicurigai akibat keganasan yang disertai sepsis dengan status fisik ASA IVE dan rencana dilakukan tindakan laparotomi dengan anestesi umum. Pasien ini telah dipasang kateter vena sentral saat di IGD. Pasien dilakukan tindakan anestesi umum selama 3 jam dan mendapatkan cairan intra operatif $1.500 \mathrm{cc}$ melalui kateter vena sentral. Pascaoperasi pasien tidak dapat dilakukan ekstubasi karena napas tidak adekuat dan hemodinamik tidak stabil sehingga pasien dirawat di ruang ICU.

Saat pasien tiba di ruang ICU pada pemeriksaan fisis didapatkan kesadaran somnolen, jalan napas paten dengan terpasang endotracheal tube (ETT) nomor 7,5 mm dengan kedalaman $21 \mathrm{~cm}$, frekuensi napas 3436x/menit, suara napas paru kanan menurun dan perkusi redup pada paru kanan. Akral dingin, nadi perifer teraba kecil dan cepat, frekuensi denyut jantung 140x/menit, suara jantung dalam batas normal, tekanan darah 90/55 (MAP $66 \mathrm{mmHg}$ ) dengan terpasang norepinefrin $0,1 \mathrm{mcg} / \mathrm{kgBB} / \mathrm{menit}$. Produksi urin $250 \mathrm{cc}$ dalam 3 jam terakhir warna kuning agak pekat. Dari pemeriksaan abdomen didapatkan perut agak cembung, tampak luka bekas operasi yang tertutup kasa steril, didapatkan stoma dengan produksi feses (-), pada auskultasi bising usus menurun, pada palpasi didapatkan distensi abdomen agak berkurang dibanding dengan sebelum operasi. Kemudian pasien diberikan bantuan napas dengan ventilator mode continuous mandatory ventilation (CMV) dengan pengaturan volume tidal $400 \mathrm{cc}$, frekuensi napas $24 \mathrm{x} /$ menit, rasio I: $\mathrm{E}=1: 1,5$, PEEP $8 \mathrm{~cm} \mathrm{H}_{2} \mathrm{O}, \mathrm{FiO}_{2} 100 \%$ didapatkan respons pada pasien: volume 
tidal ekspirasi 400-410 cc, frekuensi napas 30-32x/menit, peak inspiratory pressure (PIP) 26-28 $\mathrm{cmH}_{2} \mathrm{O}, \mathrm{SpO}_{2}$ 97-98\%. Hasil analisis gas darah 1 jam pascapemasangan ventilator menunjukkan hipoksemia berat dan asidosis $\mathrm{pH} 7,16 / \mathrm{PCO}_{2} 47,8 \mathrm{mmHg} / \mathrm{PO}_{2} 149,9 \mathrm{mmHg} /$ $\mathrm{HCO}_{3} 15,4 \mathrm{mmol} / \mathrm{L} / \mathrm{BE}-11,8 \mathrm{mmol} / \mathrm{L} / \mathrm{SaO}_{2}$ 98,3\%. Dari pemeriksaan foto rontgen dada ditemukan gambaran efusi pleura masif (Gambar 1). Penilaian hasil pemeriksaan di atas adalah pasien mengalami gagal napas akibat hidrotoraks masif dekstra dengan syok septik akibat infeksi intra-abdominal.

Evakuasi cairan pleura dilakukan melalui pemasangan chest tube pada kavum pleura kanan dan didapatkan kurang lebih 2,2 liter cairan berwarna kemerahan. Pascaevakuasi cairan pleura didapatkan perbaikan pada laju pernapasan yang menurun menjadi 24-26x/menit dan penurunan PIP menjadi 22-23 $\mathrm{cmH}_{2} \mathrm{O}$. Pasien juga mengalami syok septik dengan skor sequential organ failure assessment (SOFA) sebesar 9. Berdasar atas tata laksana sepsis hour-1 bundle menurut surviving sepsis campaign (SSC) 2018 maka dilakukan pemeriksaan kadar laktat, kultur darah, juga memberikan antibiotik empiris meropenem, memberikan cairan kristaloid $30 \mathrm{cc} / \mathrm{kgBB}$ apabila masih didapatkan hipotensi atau apabila kadar laktat $>4$, dan mempertahankan MAP $>65 \mathrm{mmHg}$ dengan pemberian vasopresor norepinefrin apabila pasien masih mengalami hipotensi selama atau setelah pemberian resusitasi cairan. Hasil pemeriksaan kadar laktat 4,1 mmol/L sehingga kami memberikan cairan kristaloid Ringer lactate $30 \mathrm{cc} / \mathrm{kgBB}$ selama $1 \mathrm{jam}$.

Pada perawatan hari ke-2 di ICU, kondisi pasien semakin memburuk. Pada pemeriksaan fisis paru ditemukan ronki di kedua lapang paru. Kondisi hemodinamik tidak stabil, didapatkan akral dingin, nadi perifer teraba kuat angkat dan cepat, frekuensi denyut jantung 120-125x/menit, tekanan darah sistole 70-80 $\mathrm{mmHg}$ dan tekanan darah diastole 40-45 (MAP 60-68 mmHg) norepinefrin dinaikkan hingga dosis $0,7 \mathrm{mcg} /$ $\mathrm{kgBB} /$ menit dengan tambahan vasopresin 0,03 unit/menit dan dobutamin $10 \mathrm{mcg} /$
$\mathrm{kgBB} /$ menit. Kesadaran tidak dapat dievalusi karena pasien diberikan sedasi midazolam $3 \mathrm{mg} / \mathrm{jam}$ dan deksmedetomidin $0,2 \mathrm{mcg} /$ $\mathrm{kgBB} / \mathrm{jam}$. Produksi urin 1.100 cc dalam 24 jam (setara dengan $0,76 \mathrm{cc} / \mathrm{kgBB} / \mathrm{jam}$ ) warna kuning agak pekat. Hasil laboratorium darah lengkap didapatkan kadar hemoglobin $11,2 \mathrm{mg} / \mathrm{dL}$, kadar leukosit $16.550 / \mathrm{mm}^{3}$, hematokrit 32,8\%, kadar trombosit 81.000/ $\mathrm{mm}^{3}$. Pemeriksaan kadar procalcitonin didapatkan hasil 85,83 ng/mL. Hasil analisis gas darah didapatkan mixed asidosis metabolik dan respiratorik $\mathrm{pH} 7,17, \mathrm{PCO}_{2} 53,8 \mathrm{mmHg}$, $\mathrm{PO}_{2} 84,5 \mathrm{mmHg}, \mathrm{HCO}_{3} 19,9 \mathrm{mmol} / \mathrm{L}, \mathrm{BE}-8,8$ $\mathrm{mmol} / \mathrm{L}, \mathrm{SaO}_{2}$ 93,4\%. Pengaturan ventilator masih dipertahankan seperti hari pertama karena belum didapatkan perbaikan klinis. Hasil penilaian skor SOFA naik menjadi 11 . Pada pasien ini didapatkan demam (suhu $\left.38,5^{\circ} \mathrm{C}\right)$, leukositosis $\left(16.550 / \mathrm{mm}^{3}\right)$, sekret purulen, ARDS dengan pf ratio 105 , rontgen toraks didapatkan infiltrat bilateral yang terlokalisir (Gambar 1) sehingga kita berikan antibiotik empiris levofloxacin. Dari penilaian clinical pulmonary infection score (CPIS) didapatkan nilai 7 sehingga pasien didiagnosis ventilator associated pneumonia (VAP).

Pada hari ke- 5 didapatkan candida tropicalis pada hasil kultur sputum dan urin yang sensitif terhadap fluconazole sehingga pada pasien diberikan tambahan antifungi fluconazole. Perkembangan pasien di ICU menunjukkan perbaikan klinis pada hari ke-8 (Tabel 1), mulai terjadi penurunan skor SOFA menjadi 6 dan CPIS menjadi 5, kemudian dilakukan tappering down dosis norepinefrin turun menjadi 0,2 $\mathrm{mcg} / \mathrm{kgBB} /$ menit, dobutamin turun menjadi 8 $\mathrm{mcg} / \mathrm{kgBB} /$ menit dan vasopresin dihentikan. Mode ventilator diubah dari CMV menjadi pressure control-synchronized intermitten mandatory ventilation (PC-SIMV) dengan pengaturan frekuensi napas $14 \mathrm{x} /$ menit, Pinsp $12 \mathrm{cmH}_{2} \mathrm{O}$, PEEP $5 \mathrm{cmH}_{2} \mathrm{O}$, delta Psupp 7 $\mathrm{cmH}_{2} \mathrm{O}$, rasio I : $\mathrm{E}=1: 2, \mathrm{FiO}_{2} 40 \%$ didapatkan respons pada pasien:volume tidal ekspirasi 420-450 cc, frekuensi napas 18-20x/menit, PIP $18-19 \mathrm{cmH}_{2} \mathrm{O}, \mathrm{SpO}_{2}$ 99-100\%. Analisis gas darah pada hari ke-8 didapatkan hasil $\mathrm{pH} 7,36$, $\mathrm{PCO}_{2} 41,2 \mathrm{mmHg}, \mathrm{PO}_{2} 105 \mathrm{mmHg}, \mathrm{HCO}_{3} 23,6$ 

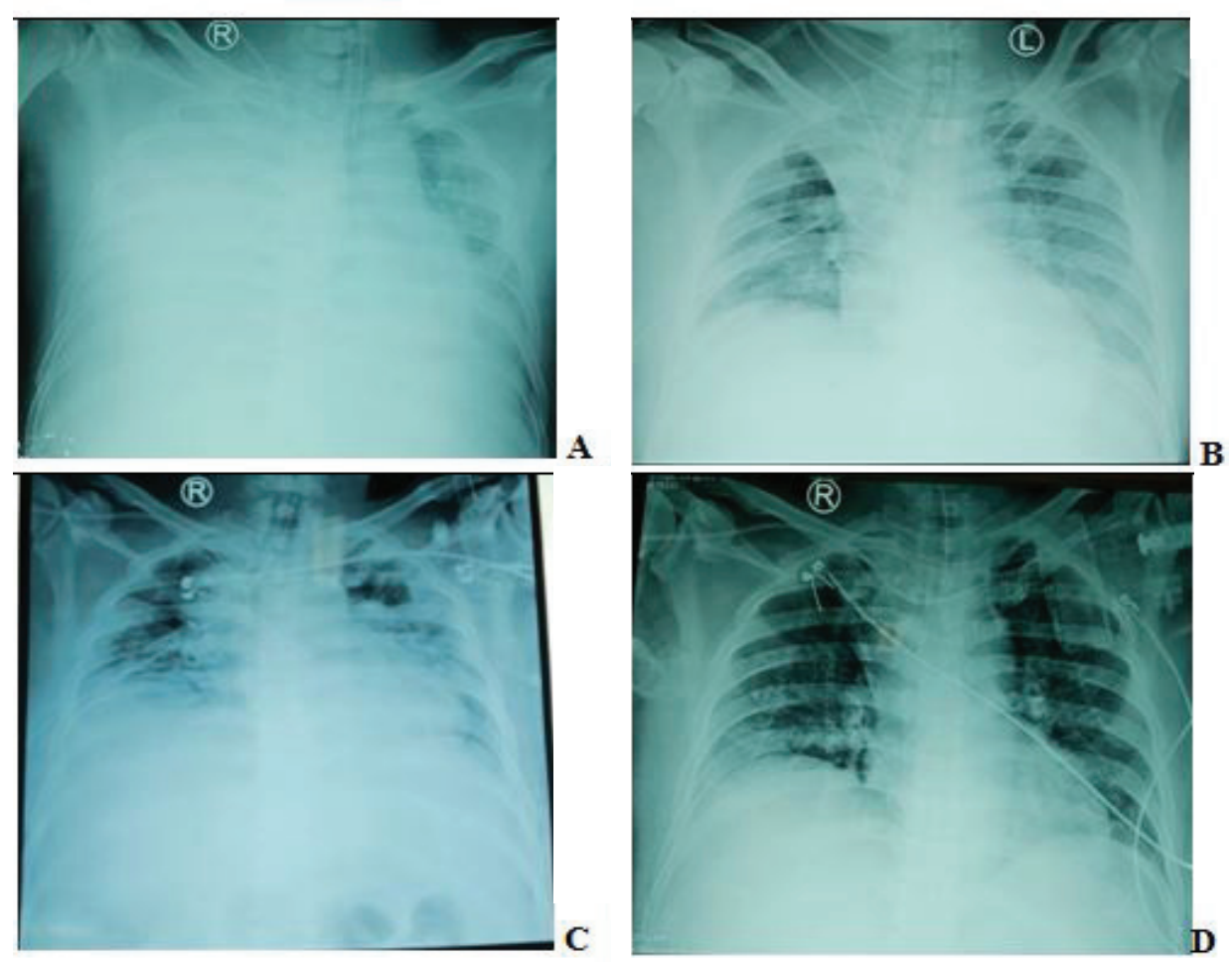

\section{Gambar 1 Perkembangan Rontgen Toraks}

Ket.: a. Rontgen toraks saat di ICU pascaeksplorasi laparotomi menunjukkan gambaran hidrotoraks masif.

b. Rontgen toraks pascaevakuasi cairan hidrotoraks sebanyak 2,2 liter dan pascapemasangan WSD.

c. Rontgen toraks perawatan hari ke-3 di ICU yang menunjukkan infiltrat bilateral.

d. Rontgen toraks perawatan hari ke-11 di ICU yang menunjukkan perbaikan.

Sumber: dokumentasi pribadi

$\mathrm{mmol} / \mathrm{L}, \mathrm{BE}-2 \mathrm{mmol} / \mathrm{L}, \mathrm{SaO}_{2} 97,8 \%$ dengan $\mathrm{FiO}_{2} 40 \%$ sehingga didapatkan pf ratio 262,5. Pada pasien juga terjadi penurunan nilai procalcitonin yang bermakna dengan kadar procalcitonin sebelumnya sebesar $85,83 \mathrm{ng} /$ mL turun menjadi $2,26 \mathrm{ng} / \mathrm{mL}$.

Pada hari ke-11 perawatan di ICU, pasien sadar penuh saat dilakukan spontaneous awake trial (SAT) dan pasien memenuhi kriteria proses weaning ventilator. Pada analisis gas darah didapatkan hasil $\mathrm{pH} 7,39$, $\mathrm{PCO}_{2} 37,8 \mathrm{mmHg}, \mathrm{PO}_{2} 85,7 \mathrm{mmHg}, \mathrm{HCO}_{3} 23,2$ $\mathrm{mmol} / \mathrm{L}, \mathrm{BE}$ : $-2 \mathrm{mmol} / \mathrm{L}, \mathrm{SaO}_{2} 96,4 \%$ dengan $\mathrm{FiO}_{2} 40 \%$ sehingga didapatkan pf ratio 214 , pertukaran gas adekuat dibuktikan dengan saturasi perifer 97-98\% dengan penggunaan fraksi $\mathrm{O}_{2} \leq 0,5$ dan PEEP $\leq 8 \mathrm{cmH}_{2} \mathrm{O}$. Ventilasi pada pasien juga adekuat, dibuktikan dengan hasil $\mathrm{pH}$ pada analisis gas darah $>7,3$. Status hemodinamik pasien stabil yang ditandai dengan tidak ada iskemia jantung, tidak ada aritmia yang tidak terkontrol, dan penggunaan vasopresor dosis minimal, yaitu norepinefrin $0,05 \mathrm{mcg} / \mathrm{kgBB} / \mathrm{menit}$ dan dobutamin $5 \mathrm{mcg} /$ $\mathrm{kgBB} /$ menit serta didapatkan kadar laktat 1,5 mmol/L. Pada hari ke-12 perawatan di ICU, kondisi klinis pasien semakin membaik. Hasil analisis gas darah pada hari ke-12 didapatkan pH 7,42, $\mathrm{PCO}_{2}: 29,7 \mathrm{mmHg}, \mathrm{PO}_{2} 91,3 \mathrm{mmHg}$, $\mathrm{HCO}_{3} 19,3 \mathrm{mmol} / \mathrm{L}, \mathrm{BE}-5,5 \mathrm{mmol} / \mathrm{L}, \mathrm{SaO}_{2}$ 97,35\% dengan $\mathrm{FiO}_{2} 35 \%$ sehingga didapatkan pf ratio 260 .

Pada hari ke-12 dilakukan spontaneous breathing trial (SBT) karena kondisi pasien telah memenuhi kriteria berikut a) kriteria respirasi $\left(\mathrm{PaO}_{2} / \mathrm{FiO}_{2}>150-200 \mathrm{mmHg}\right.$ dengan $\mathrm{FiO}_{2} \leq 50 \%$ dan PEEP $\leq 8 \mathrm{cmH}_{2} 0 ; \mathrm{PaCO}_{2}$ normal atau pada kadar baseline pasien; pasien dapat menginisiasi upaya inspiratory); b) kriteria kardiovaskular (tidak ada tanda iskemia 
Tabel 1 Perkembangan Pasien di ICU

\begin{tabular}{|c|c|c|c|c|c|c|c|c|c|c|c|c|c|c|c|}
\hline Hari & SOFA & PCT & Lak & $\begin{array}{c}\text { Plt } \\
\left(\mathrm{x} 10^{3}\right)\end{array}$ & NE & Dob & Vas & Crea & CPIS & Tem & $\begin{array}{c}\text { Leu } \\
\left(\mathrm{x} 10^{3}\right)\end{array}$ & Sekret & $\underset{\text { Ratio }}{\text { pf }}$ & $\begin{array}{l}\text { Kultur } \\
\text { Sputum } \\
\text { \& Urin }\end{array}$ & $\begin{array}{c}\text { Anti- } \\
\text { mikrob }\end{array}$ \\
\hline $\mathrm{H}-\mathrm{O}$ & 8 & - & 4,1 & 274 & 0,2 & 0 & 0 & 0,91 & 3 & 37 & 7,4 & - & 149 & - & $\mathrm{C}$ \\
\hline $\mathrm{H}-1$ & 9 & 85,83 & 4,3 & & 0,2 & 5 & 0 & 1,42 & 3 & 37,8 & - & mukoid & 143 & - & $\mathrm{M}$ \\
\hline $\mathrm{H}-2$ & 11 & - & - & 81 & 0,75 & 10 & 0,03 & 1,79 & 7 & 38,5 & 16,55 & purulen & 105 & - & $\mathrm{M} / \mathrm{L}$ \\
\hline $\mathrm{H}-3$ & 10 & - & - & 60 & 1 & 15 & 0,03 & 0,96 & 7 & 39 & 11,66 & purulen & 101 & - & $\mathrm{M} / \mathrm{L}$ \\
\hline $\mathrm{H}-4$ & 10 & - & 3,1 & & 0,7 & 10 & 0,02 & 0,85 & 7 & 39,2 & - & purulen & 103 & - & $\mathrm{M} / \mathrm{L}$ \\
\hline H-5 & 9 & - & - & 37 & 0,5 & 10 & 0,01 & 0,72 & 9 & 39,5 & 6,69 & purulen & 125 & C. trop & $\begin{array}{c}\mathrm{M} / \mathrm{L} / \\
\mathrm{F}\end{array}$ \\
\hline H-6 & 8 & - & - & 63 & 0,2 & 8 & 0 & 0,74 & 8 & 38,2 & 7,48 & purulen & 225 & - & $\begin{array}{c}\text { M/L/ } \\
\text { F }\end{array}$ \\
\hline $\mathrm{H}-7$ & 7 & - & 2 & & 0,1 & 8 & 0 & 0,67 & 7 & 38 & - & purulen & 202 & - & $\begin{array}{c}\text { M/L/ } \\
\text { F }\end{array}$ \\
\hline $\mathrm{H}-8$ & 6 & - & - & 142 & 0,1 & 8 & 0 & 0,5 & 5 & 37,8 & 7,14 & purulen & 262 & - & $\begin{array}{c}\text { M/L/ } \\
\text { F }\end{array}$ \\
\hline H-9 & 6 & 2,26 & 1,7 & - & 0,1 & 8 & 0 & - & 5 & 37,5 & - & $\begin{array}{l}\text { muko- } \\
\text { purulen }\end{array}$ & 261 & - & $\begin{array}{c}\mathrm{M} / \mathrm{L} / \\
\mathrm{F}\end{array}$ \\
\hline $\mathrm{H}-10$ & 6 & - & - & - & 0,05 & 6 & 0 & - & 5 & 37,2 & - & $\begin{array}{l}\text { muko- } \\
\text { purulen }\end{array}$ & 244 & - & $\begin{array}{c}\mathrm{M} / \mathrm{L} / \\
\mathrm{F}\end{array}$ \\
\hline H-11 & 6 & - & 1,5 & - & 0,05 & 5 & 0 & - & 5 & 37 & - & mukoid & 214 & - & $\begin{array}{c}\text { M/L/ } \\
\text { F }\end{array}$ \\
\hline $\begin{array}{c}\mathrm{H}-12 \\
\text { (SBT } \\
\& \\
\text { extub) }\end{array}$ & 4 & - & - & 323 & 0 & 3 & 0 & 0,45 & 3 & 37 & - & $\begin{array}{l}\text { muko- } \\
\text { serous }\end{array}$ & 260 & - & $\begin{array}{c}\mathrm{M} / \mathrm{L} / \\
\mathrm{F}\end{array}$ \\
\hline $\mathrm{H}-13$ & 0 & - & - & - & 0 & 0 & 0 & - & 3 & 36,8 & - & - & 285 & - & F \\
\hline $\begin{array}{c}\text { H-14 } \\
\text { (keluar } \\
\text { dari } \\
\text { ICU) }\end{array}$ & 0 & - & - & - & 0 & 0 & 0 & - & 3 & 36,6 & - & - & 330 & sterile & - \\
\hline
\end{tabular}

Keterangan: C: Ciprofloxacin; M: Meropenem, L: Levofloxacin, F: Fluconazole; PCT: Procalcitonin (ng/mL); Lak: Laktat (mmol/L); Plt: Platelet ( $\mu \mathrm{L})$; NE: Norpepinefrin (mcg/kgBB/menit); Dob: Dobutamin (mcg/kgBB/menit); Vas: Vasopresin (unit/menit); Creat: Creatinine (mg/dL); Tem: Temperatur $\left({ }^{\circ} \mathrm{C}\right)$; Leu: Leukosit $(\mu \mathrm{L})$.

miokardium, denyut jantung $\leq 140 x /$ menit, tekanan darah cukup dengan vasopresor dosis minimal atau tanpa vasopresor); c) status mental layak pasien sadar dengan GCS 4x6; d) tidak didapatkan kondisi komorbid (tidak ada demam atau sepsis yang belum terkontrol dan tidak ada ketidakseimbangan elektrolit). ${ }^{9}$ Mode ventilator PC-SIMV diganti ke mode spontan pressure support (PS). Enam jam kemudian pasien dipasang alat "T-piece" karena kondisi pasien tercapai sesuai kriteria berikut: a) volume tidal 4-6 mL/kgBB; b) laju pernapasan 30-38 kali per menit; c) rasio laju pernapasan:volume tidal 60-105 kali/L; d) maximum inspiratory pressure (Pmax)
-15 hingga -30 cm $\mathrm{H}_{2} \mathrm{O} .{ }^{9}$ Pasien memenuhi kriteria untuk dilakukan ekstubasi, yaitu pasien sadar penuh dan kooperatif, bernapas spontan dengan frekuensi napas $\leq 25 \mathrm{x} /$ menit, volume tidal $\geq 300 \mathrm{~mL} .{ }^{10}$ Kemudian dilakukan tindakan ekstubasi pada pasien. Satu hari pascaekstubasi, kondisi pasien stabil dan tidak didapatkan tanda-tanda distres napas. Pasien kemudian dipindahkan dari ICU ke ruang rawat High Care Unit Bedah pada hari ke-14.

\section{Pembahasan}

Pada kasus ini, pasien didiagnosis hidrotoraks pascapemasangan CVC. Hidrotoraks adalah 
Tabel 2 Pengaturan Ventilator pada Pasien ARDS

\begin{tabular}{|c|c|}
\hline Setting & Recommendation \\
\hline Mode & $\mathrm{A} / \mathrm{C}(\mathrm{CMV})$ in most acute stage, pressure support for mild ARDS and during recovery \\
\hline Rate & $20-40 / \mathrm{min} ;$ avoid auto-PEEP \\
\hline $\begin{array}{l}\text { Volume/pressure } \\
\text { control }\end{array}$ & Pressure or volume \\
\hline Tidal volume & $4-8 \mathrm{~mL} / \mathrm{kg}$ and plateau pressure $<28 \mathrm{~cm} \mathrm{H}_{2} \mathrm{O}$ \\
\hline Driving pressure & $<15 \mathrm{~cm} \mathrm{H}_{2} \mathrm{O}$ \\
\hline Inspiratory time & $\begin{array}{l}\text { Ensure synchrony in patient-triggered ventilation }(0,5-0,8 \mathrm{~s}) \text {, may incorporate a short } \\
\text { end-inspiratory pause in passive ventilation }\end{array}$ \\
\hline PEEP & 8-20 $\mathrm{cm} \mathrm{H}_{2} \mathrm{O}$; lowest level to achieve $\mathrm{SpO}_{2} / \mathrm{PaO}_{2}$ target \\
\hline $\mathrm{FiO}_{2}$ & As needed to achieve $\mathrm{SPO}_{2} 88 \%-95 \% / \mathrm{PaO}_{2} 55-88 \mathrm{mmHg}$ \\
\hline Synchrony & Assess and avoid flow mismatch and double triggering \\
\hline
\end{tabular}

Keterangan: CMV, continuous mandatory ventilation; PEEP, positive end expiratory pressure. Sumber: Hess \& Kacmarek. ${ }^{15}$

kumpulan cairan dalam rongga pleura. Pada beberapa studi laporan kasus dinyatakan bahwa ujung tip CVC dapat bermigrasi ke dalam sistem vena pulmonalis sehingga menyebabkan efusi pleura sekunder akibat peningkatan tekanan hidrostatik. Batas sebelah kanan dari vena kava superior, azygous, hemiazygous dan thoracic interna berbatasan langsung dan berdekatan dengan pleura. Kerusakan pembuluh darah tersebut oleh guide wire CVC dapat menyebabkan perdarahan ke cavum pleura yang bertekanan rendah. Apabila ujung tip kateter CVC berada di dalam kavum pleura maka dapat menyebabkan hemotoraks/fluidotoraks efusi pleura. ${ }^{11}$ Pada pasien ini terjadi malposisi kateter CVC dan kateter masuk ke dalam kavum pleura. Pascapemberian cairan intraoperatif 1.500 cc melalui kateter vena sentral pasien mengalami distres napas dan dibuktikan dengan pemeriksaan penunjang rontgen toraks terjadi hidrotoraks pada kavum pleura kanan.

Evakuasi/drainase cairan di pleura dapat memperbaiki ventilasi mekanik, yaitu dapat menurunkan plateau pressure serta meningkatkan end-expiratory transpulmonary pressure, komplians sistem respirasi, endexpiratory lung volume, dan $\mathrm{PaO}_{2} / \mathrm{FiO}_{2}$ ratio. ${ }^{12}$ Akan tetapi, pada pasien ini juga didapatkan sepsis yang menginduksi acute respiratory distress syndrome (ARDS). Sepsis ditandai dengan respons terhadap inflamasi yang

Tabel 3 Target Pertukaran Udara, Tekanan, dan Volume Tidal pada Pasien ARDS

\begin{tabular}{|c|c|}
\hline $\mathrm{PaO}_{2}$ & $55-80$ mm Hg; $\mathrm{SpO}_{2} 88-95 \%$ \\
\hline $\mathrm{PaCO}_{2}$ & $40 \mathrm{~mm} \mathrm{Hg}$ if possible \\
\hline $\mathrm{pH}$ & $\begin{array}{l}7,2-7,4 \\
\text { Permissive hypercapnia to avoid high Pplat and driving pressure }\end{array}$ \\
\hline PEEP & As necessary to maintain alveolar recruitment $\left(8-20 \mathrm{ch} \mathrm{H}_{2} \mathrm{O}\right)$ \\
\hline Plateau pressure & $<28 \mathrm{~cm} \mathrm{H}_{2} \mathrm{O}$ \\
\hline Driving pressure & $<15 \mathrm{~cm} \mathrm{H}_{2} \mathrm{O}$ \\
\hline Tidal volume & $6 \mathrm{~mL} / \mathrm{kg}$ PBW (4-8 mL/kg PBW) \\
\hline $\mathrm{FiO}_{2}$ & Lowest $\mathrm{FiO}_{2}$ for $\mathrm{PaO}_{2} 55-80 \mathrm{~mm} \mathrm{Hg}$ and $\mathrm{SpO}_{2} 88 \%-95 \%$ \\
\hline
\end{tabular}

Keterangan: PBW, predicted body weight; PEEP, positive end expiratory pressure; Pplat, plateau pressure Sumber : Hess \& Kacmarek. $^{15}$ 


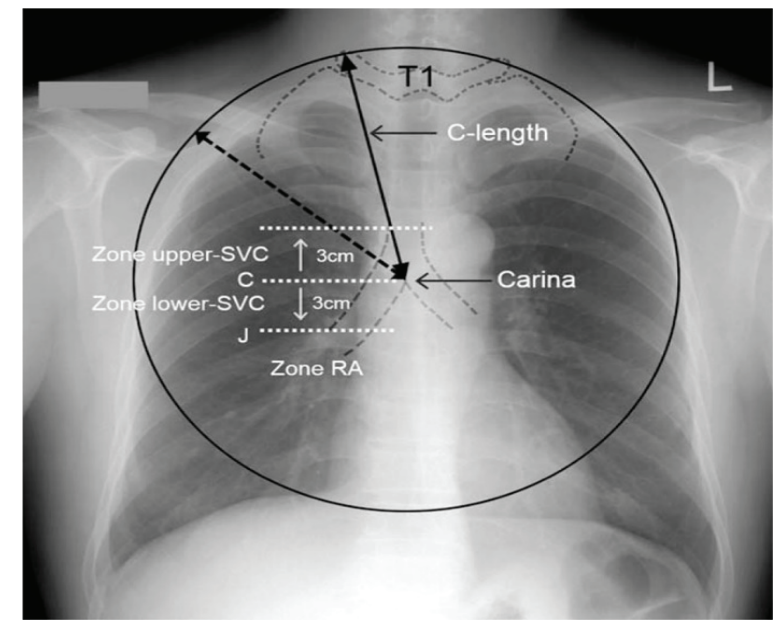

Gambar 2 Zona Peletakan Ujung/Tip Kateter CVC

Ket.: C-length:jarakantara tepivertebratorakal 1 hingga carina; C: selevel dengan carina; $\mathrm{J}$ :persimpanganantaravenakavasuperior dengan atrium kanan; Lower SVC: antara carina $3 \mathrm{~cm}$ dibawahnya; RA(rightatrium): di bawah J; SVC (superior vena cana): vena kava superior; upper SVC: antara carina dan $3 \mathrm{~cm}$ di atasnya Sumber: Lee $\&$ Lee. ${ }^{21}$

berlebihan akibat infeksi patogen. ${ }^{13}$

Acute respiratory distress syndrome (ARDS) ditandai oleh edema pulmonum yang bukan disebabkan oleh penyebab kardiak dengan onset yang akut disertai infiltrat paru bilateral dan penurunan komplians dari sistem respiratorik. Berdasar atas definisi tersebut, ARDS merupakan kondisi akut injuri paru yang difus dengan kriteria sebagai berikut: (1) onset dalam 1 minggu akibat penyebab klinis yang baru/akibat perburukan gejala respiratorik; (2) opasitas bilateral pada rontgen toraks yang sepenuhnya tidak disebabkan oleh efusi, kolaps paru, atau nodul; (3) diagnosis gagal napas tidak disebabkan oleh gagal jantung atau kelebihan cairan; (4) hipoksemia, seperti yang dijelaskan dengan rasio $\mathrm{PaO}_{2} / \mathrm{FiO}_{2}$ yang diukur dengan penggunaan PEEP $\geq 5 \mathrm{~cm} \mathrm{H}_{2} \mathrm{O}$ sehingga dapat mengidentifikasi 3 kategori: ringan (200 $\mathrm{mmHg}<\mathrm{PaO}_{2} / \mathrm{FiO}_{2} \leq 300 \mathrm{~mm} \mathrm{Hg}$ ), sedang (100 $\left.\mathrm{mmHg}<\mathrm{PaO}_{2} / \mathrm{FiO}_{2} \leq 200 \mathrm{mmHg}\right)$, berat $\left(\mathrm{PaO}_{2} /\right.$ $\left.\mathrm{FiO}_{2} \leq 100 \mathrm{mmHg}\right) .{ }^{14}$ ARDS merupakan sindrom heterogen yang ditandai dengan peningkatan permeabilitas sel endotel kapilar pulmonari. ${ }^{13}$ Patologi ARDS melalui dua fase, fase pertama ditandai dengan respons inflamatori hebat yang menyebabkan kerusakan alveolar dan endotelial, peningkatan permeabilitas vaskular, dan peningkatan cairan pada paru. Fase ini terjadi pada 7-10 hari dan kemudian sering kali berkembang menjadi fibrosis luas (fase 2). ${ }^{15}$

Faktor risiko ARDS berupa injuri langsung pada paru (pneumonia, aspirasi isi lambung, kontusio pulmo, tenggelam, trauma inhalasi, emboli lemak) dan injuri yang bersifat tidak langsung pada paru (sepsis, syok, pankreatitis akut, trauma multipel, overdosis obat, transfusi produk darah). ARDS pada pasien ini disebabkan oleh proses injuri akut pada paru akibat fluidotoraks yang memicu abnormalitas permeabilitas kapiler pulmonar, alveolar flooding, dan surfaktan hilang. Selain itu, ARDS pada pasien ini disebabkan oleh injuri yang bersifat tidak langsung pada paru akibat sepsis. ${ }^{13}$

Pada tahun 2016, Komite Sepsis mengeluarkan definisi baru sepsis, yaitu disfungsi organ yang mengancam nyawa yang disebabkan oleh disregulasi respons host terhadap infeksi. Syok septik adalah abnormalitas sirkulasi, selular, dan metabolik pada pasien sepsis yang menyebabkan hipotensi refrakter terhadap cairan sehingga membutuhkan terapi vasopresor yang berkaitan dengan hipoperfusi jaringan (laktat $>2 \mathrm{mmol} / \mathrm{L}$ ). SOFA merupakan sistem skoring yang objektif untuk menentukan disfungsi organ mayor, berdasar atas kadar oksigen (partitekanan parsial oksigen dan fraksi oksigen inspirasi), hitung jumlah trombosit, skor glasgow coma scale, kadar bilirubin, kadar kreatinin (atau produksi urin), dan mean arterial pressure (atau apakah obat vasoaktif dibutuhkan). SOFA rutin digunakan di praktik klinik dan penelitian dalam mendiagnosis kegagalan organ pada pasien kritis. qSOFA lebih sederhana. Prediktor disfungsi organ dari kriteria qSOFA, antara lain laju pernapasan $>22 x /$ menit, tekanan darah sistole $100 \mathrm{mmHg}$ atau lebih rendah, gangguan status mental (glasgow coma scale score $<15$ ). Skor qSOFA $\geq 2$ dengan kecurigaan infeksi atau sudah ada infeksi yang pasti 


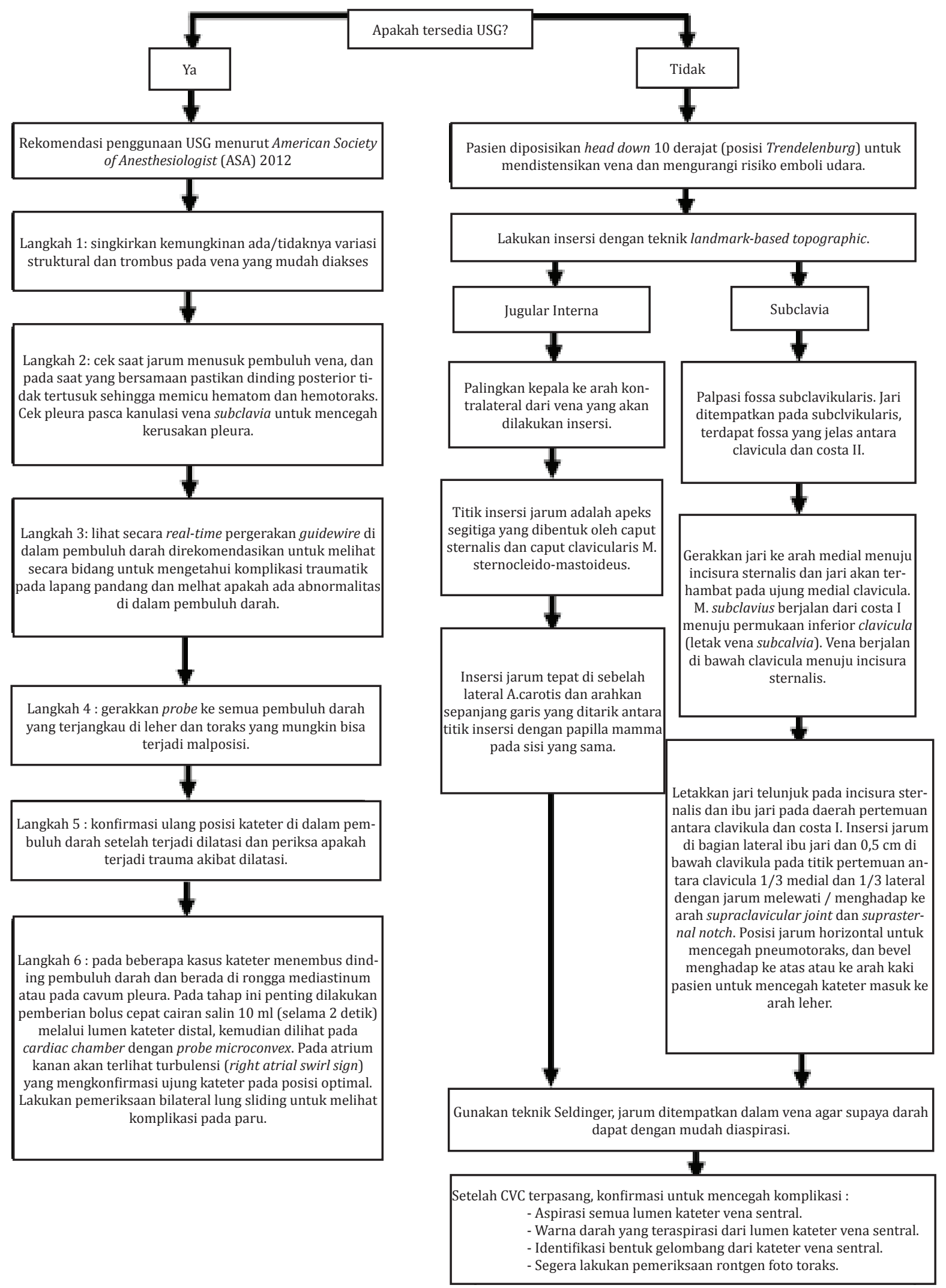

Gambar 3 Rekomendasi Pemasangan CVC untuk Menghindari Malposisi

Sumber: Lee, $\mathrm{dkk}^{21}$ 
diusulkan untuk memberikan terapi yang agresif, termasuk monitoring yang sering dan perawatan di ICU. ${ }^{16}$

Pada studi prelinik, ternyata sepsis dapat menyebabkan injuri langsung pada paru diawali dengan kerusakan pada epitel paru, namun injuri secara tidak langsung juga dapat terjadi yang bermula dari kerusakan endotelial sistemik akibat mediator inflamatori. ${ }^{6}$ Unit pertukaran gas di paru dibatasi oleh barier alveolar-kapilar yang tipis yang memelihara hubungan antara udara dan cairan. Barier tersebut mempunyai 3 komponen: (1) lapisan sel epitelial (baik tipe I [AT1] atau tipe II [AT2] pneumosit, (2) lapisan sel endotelial mikrovaskular, dan (3) ruang intersisial antara permukaan epitelial dan endotelial. Makrofag alveolar menempati secara langsung permukaan atas epitelial pulmonar. Konsep utama yang menerangkan injuri paru pada ARDS adalah hilangnya barier tersebut. Sepsis yang menginduksi injuri dapat menginisiasi bagian epitelial(injurilangsungpada paru)atau pada bagian endotelial (injuri tidak langsung pada paru). Disfungsi barier akibat sepsis yang menginduksi ARDS dapat juga terjadi akibat infeksi yang berasal dari paru (contoh: pneumonia) atau dari infeksi ekstrapulmonar (contoh: infeksi intraabdomen). Organ paru mempunyai alveoli hampir $480 \times 10^{6}$ yang dapat berdiferensiasi ketika terjadi ARDS, menghasilkan heterogenesitas yang banyak, dengan injuri yang berat pada beberapa area paru. ${ }^{17}$

Sepsis yang menginduksi ARDS berasal dari infeksi di paru (injuri langsung) atau berasal dari sumber ekstraparu (injuri tidak langsung). Respons host terhadap patogen adalah pengumpulan sel-sel inflamatori yang melepaskan sitokin proinflamatori dan jalur lainnya yang merusak barier alveolar-kapilar. Kehilangan integritas barier tersebut memicu cairan masuk ke dalam alveolus dan injuri paru. Sepsis secara tidak langsung menginduksi ARDS yang berasal dari infeksi di luar paru. Mekanisme yang mendasari terjadi injuri paru dari sumber infeksi yang jauh dari paru adalah multifaktorial dan belum sepenuhnya dipahami. Saluran pencernaan mempunyai peran penting dalam terjadi injuri paru, baik sebagai sumber infeksi utama atau akibat integritas barier yang hilang karena infeksi. ${ }^{17}$

Sumber infeksi sepsis pada pasien ini berasal dari saluran pencernaan. Peningkatan permeabilitas saluran cerna dapat memicu pelepasan mediator yang berperan pada injuri paru. Pelepasan mediator toksik dari saluran cerna dapat bermigrasi ke paru melalui sistem limfatik mesenterium yang dikenal sebagai hipotesis "gut-lymph". Kondisi alami paru yang mempunyai banyak vaskular dan ada fakta bahwa semua darah yang dipompa dari jantung akan bersirkulasi melalui sirkulasi pulmonar dapat memicu injuri pada organ. Kerusakan pada barier alveolar-kapilar dapat dipicu oleh perubahan sel endotelial mikrovaskular melalui formasi mikrotrombus. Injuri pada permukaan sel endotelial, melalui perubahan pada glikokalik, pembentukan agregasi platelet-leukosit, dan dipicu oleh mediator inflamatori yang juga dapat memfasilitasi hilangnya fungsi barier alveolar-kapilar. Oleh sebab itu, dibanding dengan injuri langsung pada paru, jalur mekanisme injuri endotelial tidak sama dengan injuri tidak langsung pada paru. Konsep ini didukung dengan observasi biomarker yang berkaitan dengan disfungsi endotelial (angiopoietin-1) yang meningkat pada pasien ARDS dengan injuri tidak langsung pada paru dibanding dengan pasien yang mengalami ARDS karena injuri langsung pada paru. ${ }^{17}$

Berdasar atas publikasi "surviving sepsis campaign: international guidelines for management of sepsis and septic shock" pada tahun 2016, manajemen sepsis direvisi menjadi "hour-1 bundle". Perubahan yang penting terletak pada revisi SSC bundles yaitu pada 3- $h$ dan 6-h yang digabung jadi satu "hour-1 bundle" dengan tujuan yang eksplisit untuk memulai resusitasi dan untuk penatalaksanaan dengan segera. Resusitasi cairan mungkin dibutuhkan dalam waktu lebih dari 1 jam, namun inisiasi resusitasi dan tata laksana seperti melakukan pemeriksaan kultur darah dan kadar laktat, pemberian cairan dan antibiotik, dan pada kasus hipotensi yang mengancam nyawa, pemberian terapi vasopresor lebih awal dapat 
dimulai segera. Berikut perubahan Hour1 surviving sepsis campaign bundle of care 2018: a) mengukur kadar laktat; b) periksa kultur darah; c) berikan antibiotik spektrum luas; d) berikan cairan kristaloid $30 \mathrm{cc} / \mathrm{kgBB}$ apabila didapatkan hipotensi atau kadar laktat $>4 \mathrm{mmol} / \mathrm{L}$; e) berikan vasopresor apabila pasien mengalami hipotensi selama atau setelah pemberian resusitasi cairan untuk mempertahankan MAP $\geq 65 \mathrm{mmHg} .{ }^{18}$

Pasien sepsisyangmenginduksi ARDS sering membutuhkan ventilasi mekanik. ${ }^{17}$ Pasien ARDS terjadi hipoksemia dan peningkatan kerja pernapasan. Bantuan pernapasan diindikasikan agar mampu menghilangkan hipoksemia dengan penggunaan PEEP, pemberian fraksi oksigen yang tinggi, dan pengurangan kerja pernapasan. Kemampuan untuk ventilasi dapat terganggu diakibatkan retensi $\mathrm{CO}_{2}$. Pada tahap ini, ventilasi mekanik diindikasikan karena terjadi kegagalan ventilasi akut. Penggunaan masker continuous positive airway pressure (CPAP) dan ventilasi non-invasif tidak direkomendasikan untuk pasien ARDS. ${ }^{15}$

Prinsip utama bantuan ventilasi pada pasien ARDS adalah jaga oksigenasi yang cukup dan minimalisir terjadi cedera pada paru akibat penggunaan ventilator. ${ }^{10,19}$ Prinsip penanganan bantuan napas pada pasien ini dengan lung protective ventilation strategy. Prinsip dari lung protective ventilation strategy yang diterapkan pada pasien ini adalah volume tidal $6 \mathrm{~mL} / \mathrm{kgBB}$ dari nilai predicted body weight dan plateau pressure $<30 \mathrm{~cm} \mathrm{H}_{2} \mathrm{O}$ ). Beberapa penelitian retrospektif menyarankan supaya volume tidal tidak terlalu besar dengan plateau pressures $<30 \mathrm{~cm} \mathrm{H}_{2} \mathrm{O}$, karena plateau pressures yang rendah berkaitan dengan angka kematian yang kecil. Untuk meningkatkan pertukaran gas dan menghindari atelektotrauma, PEEP dapat diaplikasikan. Permissive hypercapnia yang dikombinasi dengan volume tidal dan minute ventilation yang rendah merupakan komponen penting dalam lung protective ventilation strategy. Permissive hypercapnia dapat diaplikasikan pada pasien sepsis yang memicu ARDS. ${ }^{13}$

ARDS yang menetap itu membutuhkan penilaian selama 24 jam setelah penggunaan PEEP $\geq 10 \mathrm{~cm} \quad \mathrm{H}_{2} \mathrm{O}$ dengan penggunaan $\mathrm{FiO}_{2} \geq 0,5$. Evaluasi ARDS dengan computed tomography (CT) toraks mampu menunjukkan penyakit yang heterogen dengan konsolidasi, area yang kolaps dan area yang normal pada jaringan paru. ${ }^{15}$ Secara keseluruhan strategi penanganan ARDS tidak jauh berbeda dengan penanganan pasien sepsis yang memicu ARDS, dan pemberian oksigenasi yang adekuat ke jaringan merupakan tujuan utama. ${ }^{13}$

Untuk mencegah komplikasi serius akibat pemasangan kateter vena sentral, penting melakukan atau memperhatikan tindakan berikut setelah pemasangan CVC: 1) aspirasi semua lumen kateter vena sentral; 2) warna darah yang teraspirasi dari lumen kateter vena sentral; 3) apabila sudah terpasang transduser, bentuk gelombang dapat menunjukkan peletakan dari kateter vena sentral; 4) segera lakukan rontgen foto toraks untuk mengonfirmasi bahwa kateter vena sentral berada pada tempat yang sesuai. ${ }^{11}$ Rontgen toraks pascapemasangan CVC dapat membantu mengevaluasi posisi ujung kateter apakah normal atau abnormal kaitannya dengan carina dan dapat mengonfirmasi letak kateter yang tepat. Rekomendasi terbaru ujung kateter terletak tepat di atas pertemuan vena kava superior dan atrium kanan pada level carina. Carina terletak 0,05 $\mathrm{cm}$ di atas kavum perikardial yang melintang pada vena kava superior. ${ }^{20}$

Penggunaan ultrasound dapat mengurangi angka komplikasi dan meningkatkan kualitas dan keamanan saat pemasangan CVC. ${ }^{22}$ Penggunaan ultrasound direkomendasikan pada kateterisasi vena sentral yang membantu visualisasi struktur anatomi dan mengonfirmasi patensi vena sehingga dapat menghindari puncture yang tidak pasti atau kanulasi yang tidak berhasil. ${ }^{23}$ Berdasar atas petunjuk terbaru menurut American Society of Anesthesiologists (ASA) 2012, USG sebaiknya digunakan saat melakukan puncture vena dan dapat mengonfirmasi posisi guidewire di dalam pembuluh vena. Bagaimanapun, dengan penggunaan USG dapat mengonfirmasi arah guidewire dan mengetahui letak ujung/tip 
kateter CVC dibanding dengan konfirmasi yang biasanya dilakukan dengan pemeriksaan rontgen toraks. ${ }^{24}$

Insidensi komplikasi pada pemasangan kateter vena sentral via jugular interna lebih rendah (0,5-2\%) dibanding dengan tanpa menggunakan USG (2,3-10\%). ${ }^{23}$ Pemasangan CVC pada vena jugular internal, penggunaan ultrasound berguna untuk membantu visualisasi hubungan antara vena jugular interna dan arteri karotis. Pada studi cohort 64 pasien pembedahan bedah saraf dengan risiko tinggi, kanulasi sukses dilakukan $100 \%$ dengan bantuan ultrasound, dan tidak didapatkan injuri pada arteri karotis, meskipun prosedur kanulasi dilaksanakan dengan posisi kepala dielevasi 30 derajat dan terdapat penyimpangan anatomi vena jugular interna pada 39\% pasien. Suatu studi prospektif dengan kontrol acak pada 1.332 pasien, kanulasi vena jugularis interna dengan bantuan ultrasound pada posisi netral tingkat keamanannya sama apabila dibanding dengan posisi elevasi 45 derajat. ${ }^{25}$ Pada kanulasi vena subklavia dengan bantuan ultrasound, pasien lebih aman diposisikan head down 10 derajat (posisi Trendelenburg) untuk mengurangi risiko emboli udara. ${ }^{26}$

Berikut rekomendasi pemasangan CVC dengan bantuan USG: a) gunakan transduser linear yang berfrekuensi tinggi dengan sarung dan gel steril dalam melakukan prosedur pemasangan akses vaskular; b) pergunakan ultrasound dua dimensi untuk mengevaluasi variasi anatomi dan pastikan tidak ada trombosis vaskular pada area kanulasi; c) penggunaan ultrasound dalam membantu kateterisasi vena jugular interna secara realtime (dinamis) dapat menurunkan risiko komplikasi mekanik dan infeksi, menurunkan jumlah tusukan pada area insersi, menurunkan lama waktu kanulasi, dan meningkatkan angka keberhasilan prosedur; d) operator dianjurkan melakukan prosedur pemberian cairan salin bolus cepat dengan bantuan ultrasound untuk melihat right atrial swirl sign (RASS) dalam mendeteksi ujung/tip kateter; e) pasca prosedur pemasangan CVC direkomendasikan untuk dilakukan pemeriksaan bilateral lung sliding mempergunakan transduser linear berfrekuensi tinggi sebelum dan setelah insersi CVC pada vena jugular interna dan vena subklavia untuk mendeteksi komplikasi pneumotoraks. ${ }^{22}$

\section{Simpulan}

Pasien gagal napas yang disebabkan oleh hidrotoraks masif dekstra akibat komplikasi pemasangan kateter vena sentral via vena jugularis interna dekstra dengan penyulit ARDS dan syok septik membutuhkan evakuasi cairan di kavum pleura segera untuk memperbaiki ventilasi dan oksigenasi. Penanganan syok septik dan ARDS berfokus pada prinsip lung protective strategy dan sepsis bundle sesuai dengan surviving sepsis campaign (SSC) 2018. Tata laksana yang cepat dan tepat pada pasien tersebut menjadikan outcome yang baik.

\section{Daftar Pustaka}

1. Jha M, Kumar S, Bokil S, Galante D. Complications of central venous catheter cannulation in tertiary care hospital ICU, a 2 years retrospective, observational study. Pediat Anesth Crit Care J. 2013;1(2):8792.

2. Adipurna RP, Fatoni AZ. Catheter related bloodstream infection (CRBI) management in the Intensive Care Unit (ICU). J Anaesth Pain. 2020;1(2):11-8.

3. Wong AVK, Arora N, Olusanya O, Sharif B, Lundin RM, Dhadda A, dkk. Insertion rates and complications of central lines in the UK population: a pilot study. J Intens Care Soc. 2018;19(1):19-25.

4. Omar HR, Fathy A, Elghonemy M, Rashad R, Helal E, Mangar D, dkk. Massive hydrothorax following subclavian vein catheterization. Intern Archiv Med. 2010;3(32):1-3.

5. Bohendam AR, Simcock L. Central venous catheters: complications of central venous access. Dalam: Hamilton H, Bodenham AR, penyunting. Edisi ke-1. United Kingdom: Wiley-Blackwell; 2009. hlm. 175-9.

6. Kim SH, Her C. Central venous catheterrelated hydrothorax. Korean J Crit Care 
Med. 2015;30(4):343-8.

7. Ki S, Kim M, Lee W, Cho H. Tension hydrothorax induced by malposition of central venous catheter. Anesth Pain Med. 2017;12:151-4.

8. Khemakhem R, Riazulhaq M, Sadok RM, Ghamdi HA. Bilateral hydrothorax after left internal jugular venous catheterization in infant. Clin Surg. 2017;(2):1-3.

9. Marino PL, Galvagno SM. Marino's The Little ICU Book. Edisi ke-2. New York: Wolters Kluwer; 2017.

10. Kreit JW. Acute respiratory distress syndrome (ARDS). Mechanical ventilation physiology and practice. Edisi ke2. England: Oxford University Press; 2018;183-206.

11. Karnik PP, Shah HB, Dave NM, Garasia M. Massive pleural effusion following central venous catheter migration: tips to remember. Pediat Anesth Crit Care J. 2016;4(2):83-5.

12. Keyvan R, Thille AW, Carteaux G, Beji O, Christian Brun-Buisson C, Brochard L, dkk. Effects of pleural effusion drainage on oxygenation, respiratory mechanics, and hemodynamics in mechanically ventilated patients. Am Thorac Soc J. 2014;11(7):1018-24.

13. Kim WY, Hong SB. Sepsis and acute respiratory distress syndrome: recent update. Tubercul Respirat Dis J. 2016;79(2):53-7.

14. McCormack V, Tolhurst-Cleaver S. Acute respiratory distress syndrome. BJA Educat. 2017;17(5):161-5.

15. Hess DR, Kacmarek RM. Acute respiratory distress syndrome. Essential of mechanical ventilation. Edisi ke-3. England: Oxford University Press; 2019;181-94.

16. Dugar S, Choudhary C, Duggal A. Sepsis and septic shock: guideline-based management. Clevel Clin J Med. 2020;87 (1):64.

17. Englert JA, Bobba C, Baron R.M. Integrating molecular pathogenesis and clinical translation in sepsis-induced acute respiratory distress syndrome. JCI Insight. 2019;4(2):1-13.
18. Levy MM, Evans LE, Rhodes A. The surviving sepsis campaign bundle: 2018 update. Crit Care Med J. 2018;46(6):9971.000.

19. Kreit JW. Discontinuing mechanical ventilation. Mechanical ventilation physiology and practice. Edisi ke2. England: Oxford University Press; 2018;220-33.

20. Kwon H-J, Jeong Y-I, Jun I-G, Moon Y-J, Lee Y-M. Evaluation of a central venous catheter tip placement for superior vena cava-subclavian central venous catheterization using a premeasured length: a retrospective study. Medicine. 2018;97(2):1-4.

21. Lee JB, Lee YM. Pre-measured length using landmarks on posteroanterior chest radiographs for placement of the tip of a central venous catheter in the superior vena cava. J Int Med Res. 2010;38:134-41.

22. Saugel B, Scheeren TWL, Teboul J-L. Ultrasound-guided central venous catheter placement: a structured review and recommendations for clinical practice. Crit Care. 2017;21(1):225

23. Shin H-J, Na H-S, Koh W-U, Ro Y-J, Lee J-M, Choi Y-J, Park S. Complications in internal jugular vs subclavian ultrasoundguided central venous catheterization: a comparative randomized trial. Intensi Care Med. 2019;45:968-76.

24. Midha D, Chawla V, Kumar A, Mandal AK. Ultrasound guidance for central venous catheterization: a step further to prevent malposition of central venous catheter before radiographic confirmation. In J Crit Care Med. 2017;21(7):463-5.

25. Franco-Sadud R, Schnobrich D, Mathews BK, Candotti C, Abdel-Ghani S, Perez MG, dkk. Recommendations on the use of ultrasound guidance for central and peripheral vascular access in adults: a position statement of the society of hospital medicine.J Hosp Med. 2019;14(1):E1-22.

26. Hamilton $H$, Bodenham A. Central venous catheters. New Jersey: Wiley-Blackwell; 2009. 